Vol 5. No 1. Februari 2021

ISSN 2580-5029

\title{
Uji Ekstrak Bawang Putih Tunggal (Allium sativum L.) Terhadap Bakteriuria Escherichia coli Pada Calon Pekerja Migran Indonesia
}

\author{
Indah Sulistiyawati ${ }^{*}$, Muhammad Falah ${ }^{1}$, Ari Dwi Nurasih ${ }^{1}$ \\ ${ }^{1}$ Universitas Nahdlatul Ulama Purwokerto, Purwokerto, Indonesia \\ * indahsulistiyawati.s2@gmail.com
}

\begin{abstract}
Garlic (Allium sativum L) is a tested type of phytopharmaca because it is proven to have beneficial benefits as antibacterial and protect the body from pathogens. The majority of Indonesian Migrant Workers, especially Prospective Indonesian Migrant Workers (CPMI), are indicated to be susceptible to Urinary Tract Infection (UTI), which is caused by the bacteriuria Escherichia coli. In this study, the crude extract of single garlic (A. sativum $L$ ) will be used as an antibacterial against E. coli bateriuria in the urine sample of CPMI, with variations in the concentration of single crude extract of garlic, namely; $0 \%, 25 \%, 50 \%, 75 \%$, and $100 \%$. This research was conducted in a period of 1 (one) year from January to December 2020, with urine research samples from CPMI in the Banyumas Regency area. Extraction was carried out by extracting a single garlic using 96\% ethanol solvent in a ratio of $1: 1$, then evaporated to produce a filtrate that would be tested with a varied concentrate composition. Isolation of bacteriuria in urine samples using EMBA selective media. From a total of 37 urine samples, 17 about $46 \%$ were positive for E. coli, and 20 samples were $54 \%$ negative for E. coli. Bacteriuria that was found challenged with crude garlic extract resulted in differences in the antibacterial test at several extract concentrations with amoxicillin positive control, with One Way Anova a P-value $=0.000<0.05$, and continued with the analysis of the Post Hoc Test and the Tuckey Test, that the garlic extract The single most effective used as an anti-bacterial agent is the concentration of 100\%, resulting in an average inhibition of $12.81 \mathrm{~mm}$. The ability of single garlic extract to inhibit increases with increasing extract concentrate.
\end{abstract}

Keywords: single garlic (Allium sativum L), urinary tract infection, Escherichia coli, prospective Indonesian migrant workers

\section{ABSTRAK}

Bawang putih (Allium sativum L) merupakan salah satu jenis fitofarmaka yang teruji karena terbukti memiliki manfaat yang menguntungkan sebagai antibakteri dan melindungi tubuh dari pathogen. Mayoritas Pekerja Migran Indonesia khususnya Calon Pekerja Migran Indonesia (CPMI) diindikasikan mengalami kerentanan terhadap penyakit Infeksi Saluran Kemih (ISK), yang disebabkan oleh bakteriuria Escherichia coli. Pada penelitian ini akan digunakan ekstrak kasar Bawang Putih tunggal (A. sativum L) sebagai antibakteri terhadap bateriuria E. coli pada sampel urine CPMI, dengan variasi konsetrasi ekstrak kasar bawang putih tunggal yaitu; 0\%, 25\%, 50\%, 75\%, dan 100\%. Penelitian ini dilakukan dalam rentang waktu 1 (satu) tahun dari bulan Maret - September 2020, dengan sampel penelitian urine dari CPMI di wilayah Kabupaten Banyumas. Ekstraksi dilakukan dengan mengekstrak bawang putih tunggal menggunakan pelarut etanol 96\% dengan perbandingan 1:1, kemudian dievaporasi sampai menghasilkan filtrate yang akan diujikan dengan komposisi konsentrat bervariasi. Isolasi bakteriuria sample urine menggunakan media selektif EMBA. Dari jumlah 37 sampel urine 
diperoleh 17 sekitar 46\% sample positif ditemukan E. coli, dan 20 sampel sekitar 54\% negatif tidak ditemukan E. coli. Bakteriuria yang ditemukan diuji tantang dengan ekstrak kasar bawang putih menghasilkan adanya perbedaan uji antibakteri pada beberapa konsentrasi ekstrak dengan kontrol positif amoxicillin, dengan One Way Anova P-value $=0,000<0,05$, dan dilanjutkan dengan analisis Uji Post Hoc dan Uji Tuckey, bahwa ekstrak bawang putih tunggal yang paling efektif digunakan sebagai anti bakteri adalah konsentrasi 100\%, menghasilkan ratarata daya hambat $12,81 \mathrm{~mm}$. Kemampuan ekstrak bawang putih tunggal menghambat meningkat seiring dnegan bertambahnya konsentrat ekstrak.

Kata Kunci: bawang putih tunggal (Allium sativum L), infeksi saluran kemih, Escherichia coli, calon pekerja migran Indonesia

\section{PENDAHULUAN}

Jumlah Pekerja Migran Indonesia (PMI) tahun 2019 menurut data penempatan PMI BNP2TKI , pada bulan April-Juni sejumlah 70.258 orang, mengalami peningkatan dari tahun sebelumnya 2018 sejumlah 67.708 orang (Pusat Penelitian 2019). PMI sebelum bekerja di Luar Negeri disebut sebagai Calon Pekerja Migran Indonesia (CPMI). Sebelum keberangkatannya ke luar negeri, CPMI diwajibkan untuk mengikuti pemeriksaan kesehatan berdasarkan Peraturan Presiden RI No. 64 Tahun 2011 Tentang Pemeriksaan Kesehatan dan Psikologi Calon Tenaga Kerja Indonesia (Republik Indonesia 2011). Pola hidup CPMI selama masa pelatihan kerja di penampungan yang kurang higienis dapat mempengaruhi hasil pemeriksaan kesehatan. Salah satunya hasil pemeriksaan urine (urinalisa). Indikasi penyakit urinalisa adalah Infeksi Saluran Kemih (ISK) yang disebabkan oleh bakteriuria. Bakteriuria yang ditemukan pada kultur urine didominasi oleh Famili Enterobactericeae, genus Escherichia, selain itu ditemukan juga dari Genus Lactobacillus,

\section{Streptococcus, Staphylococcus atau}

Corynebacterium (Brubaker and Wolfe 2017).

Terapi pengobatan ISK karena bakteri saat ini menggunakan antibiotik, yang sering digunakan yaitu flourokuinolon, aminoglikosida dengan atau tanpa ampisilin, penisilin dan sefalosporin spektrum luas (Rahman 2017). Penggunaan antibiotik dapat menyebabkan terjadinya resistensi bakteri. Pengobatan menggunakan antibiotik yang tinggi sangat memberatkan Calon Pekerja Migran Indonesia. Berdasarakan uraian diatas dapat dirumuskan permasalahan bahwa diperlukan alternatif terapi bagi CPMI menggunakan pengobatan fitofarmaka berbasis bahan alam yang telah teruji, dengan biaya terjangkau dan mudah diperoleh, serta memiliki manfaat.

\section{Bawang putih (Allium sativum L.)} merupakan salah satu jenis fitofarmaka yang teruji, karena terbukti memiliki manfaat yang menguntungkan sebagai antibakteri (Petropoulos et al. 2018) dan melindungi tubuh dari patogen. Bawang putih memiliki aktivitas yang mirip dengan antibiotik modern termasuk Kloramfenikol (Abiy and 
Berhe 2016). Penggunaan bawang putih sebagai teraupetik menguntungkan pada sisitem kardiovaskular, antibakteri, antikanker, anti-inflamasi, efek hipoglikemik seperti hormon (Gaherwal et al. 2014). Senyawa Allicin adalah komponen antibakteri yang ditemukan di bawang putih. Allicin dihasilkan oleh hidrolisis enzimatik (Alliin lyase) yang memberikan efek reaksi menghambat pertumbuhan dan sintesis enzim pada bakteri (Arimaswati, et al2019). Penelitian (Eka et al. 2018) menyebutkan bahwa ekstrak bawang lanang (bawang putih tunggal selain memberikan efek proteksi lebih tinggi, juga mampu meningkatkan respon imun dan pertumbuhan dari tikus wistar.

Penelitian efek antibakteri bawang putih terhadap tiga jenis isolat penyebab penyakit yaitu Escherichia coli, Salmonella ser Typhi dan Staphylococcus aereus, menggunakan pelarut ekstrak metanol dan ekstrak kasar menghasilkan daya hambat antibakteri. Aktivitas bawang putih pada E. coli lebih efektif menggunakan kedua ekstrak tersebut, dibandingkan S. Aureus yang terhambat secara in vitro pada ekstrak kasar (Gaherwal et al. 2014). Penggunaan pelarut kloroform pada ekstrak bawang putih juga memberikan daya hambat yang tinggi untuk kedua jenis bakteri gram positif maupun negatif. Penghambatan ekstrak pelarut air bawang putih terhadap E. coli dan S. Aureus, ditunjukkan dengan kandungan ekstrak maskimal $25 \mathrm{mg} / \mathrm{ml}$, dengan isolat murni yang digunakan paling sensitif, serta isolat klinis tidak sensitif (Abiy and Berhe 2016).

Penelitian berbeda dari penelitian yang telah ada. Dalam penelitian ini, digunakan umbi bawang putih yang tunggal, yaitu kultivar dari tanaman bawang putih berumbi banyak. Penggunaan isolat klinis bakteriuria diperoleh dari kultur sampel urine calon pekerja migran Indonesia saat ini belum dilakukan penelitiannya. Penelitian sebelumnya menggunakan isolat murni. Penelitian ini bertujuan mengetahui pengaruh ekstrak kasar bawang putih tunggal (Allium sativum L) sebagai antibakteri terhadap bakteriuria E.coli pada sampel urine CPMI.

\section{METODE}

Penelitian ini merupakan penelitian eksperimental skala laboratorium dan dilakukan di Laboratorium Mikrobiologi Fakultas Biologi Universitas Jenderal Soedirman Purwokerto. Rentang waktu penelitian 1 (satu) tahun, dimulai bulan Maret - September 2020. Sampel penelitian adalah urine dari pasien Calon Pekerja Migran Indonesia yang diambil dari salah satu Sarana Kesehatan Pemeriksaan PMI (Pekerja Migran Indonesia) di wilayah Kabupaten Banyumas (Klinik Utama Rawat Jalan An-Nur Purwokerto). Jumlah sampel urine yang dibutuhkan sejumlah 37 sampel, dengan teknik purposive sampling. Pengambilan sampel non random memperhatikan kriteria khusus pada pasien 
berjenis kelamin perempuan, dengan kisaran usia 25 - 45 tahun.

Ekstraksi bawang putih tunggal (Allium sativum L), cara ekstraksi yang paling sederhana. Bahan sampel yang digunakan dihaluskan berupa serbuk kasar, dilarutkan dengan bahan pengekstraksi. Sebanyak $50 \mathrm{~g}$ bawang putih tunggal dikupas, dicuci kemudian dihaluskan. Setelah dihaluskan secara kasar kemudian diekstrak menggunakan etanol $96 \%$ dengan perbandingan dengan akuades1:1 dengan volume $100 \mathrm{ml}$. Sampel kemudian dipanaskan di dalam waterbath selama 60 menit. Setelah itu sampel didiamkan di tempat gelap selama 6 jam kemudian disaring, dan hasil filtratnya diujikan dengan komposisi konsentrat $0 \%$, 25\%, 50\%, 75\%, dan 100\% (Adhuri, et al 2018).

Isolasi sampel urine dari pasien Calon Pekerja Migran Indonesia, dengan menggunakan media khusus selektif EMBA, masa inkubasi $3 \mathrm{x} \quad 24$ jam, selanjutnya identifikasi morfologi atas isolat yang diperoleh, dengan pewarnaan gram. Reisolasi kultur bakteriuria E coli yang tumbuh, untuk dilakukan pengujian pra klinik in vitro dengan ekstrak kasar bawang putih tunggal.

Uji aktivitas antibakteri bawang putih tunggal (Allium sativum L). Dilakukan dengan pengukuran zona hambat. Suspensi bakteri sebanyak $50 \mathrm{ml}$ dimasukkan ke dalam cawan petri yang berisi media EMBA steril sebanyak $20 \mathrm{ml}$ yang sudah membeku (Katrin, et al 2015). Pada media yang sudah memadat dimasukkan cakram kertas dengan diameter $3 \mathrm{~mm}$, masing-masing diisi dengan konsentrasi ekstrak kasar 100\%, 75\%, 50\%, $25 \%$, dan $0 \%$, kemudian didiamkan selama 18 jam pada suhu kamar. Adapun digunakan kontrol positif dengan antibiotik Amoxicillin, dan kontrol negatif tanpa zat penghambat.

Penentuan diameter zona hambat dilakukan dengan cara memasukkan larutan ekstrak kasar bawang putih tunggal yang telah dibuat, ke dalam cawan petri sebanyak $20 \mu \mathrm{L}$ pada setiap kertas cakram. Kemudian diukur diameter zona hambat pada daerah bening kertas cakram dengan menggunakan jangka sorong. Tujuan perlakuan zona hambat yaitu untuk melihat seberapa besar kemampuan ekstrak kasar bawang putih tunggal dalam menghambat bakteri. Hasil pengujian aktivitas antibakteri ekstrak kasar bawang putih tunggal pada beberapa konsentrasi bila terjadinya penghambatan terhadap bakteriuria E.coli yang ditandai dengan adanya zona bening di sekitar kertas cakram.

Analisis data menggunakan uji statistik one way Anova, dan apabila terdapat perbedaan uji, maka akan dilakukan uji lanjutan menggunakan Uji Post Hoc dengan Uji Tuckey.

\section{HASIL DAN PEMBAHASAN}

Sampel kultur urine dengan karakteristik dari Calon Pekerja Migran Indonesia diambil dengan teknik purposive sampling, memperhatikan pengambilan 
sampling non random, dan kriteria khusus yaitu sampling dari pasien berjenis kelamin perempuan, diperoleh 37 sampel urine. Sampel tersebut telah dilakukan isolasi menggunakan media selektif EMBA, dengan masa inkubasi $2 \times 24$ jam, dilakukan identifikasi morfologi atas isolat yang diperoleh dengan pewarnaan gram, yaitu jenis bakteri kelompok gram negatif dengan bentuk basil yang sesuai dengan ciri morfologi bakteri E. coli.

Penelitian (Schmidt et al. 2017) menyatakan bahwa keberadaan bakteri patogen sangat dimungkinkan ditemukan dan diisolasi dari kultur urine. Kemudian diperoleh hasil $54 \%$ tidak ditemukan bakteriuria Escherichia coli (negatif) dan 46 $\%$ ditemukan E. coli (positif) (gambar 1). Rahman (2017) menyatakan bahwa frekuensi bakteri graman negatif pada sampel urine sebanyak $48,7 \%$ dengan jenis kelompok bakteri E. coli sebanyak 13\%.

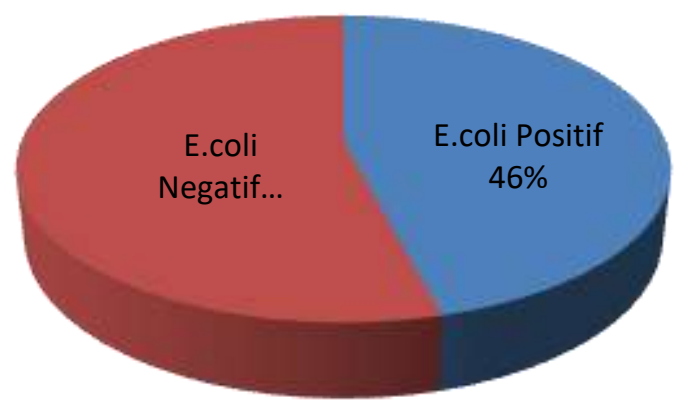

Gambar 1. Data isolasi bakteriuria E.coli dari sample urine Calon Pekerja Migran Indonesia (CPMI)

Isolat bakteri e.colli dari sampel urine CPMI kemudian, dilanjutkan pada Uji aktivitas antibakteri bawang putih tunggal (Allium sativum L) terhadap zona hambat pada pertumbuhan bakteri E.coli. Penentuan zona hambat dilakukan dengan melakukan pengukuran pada diameter zona hambat dengan menggunakan jangka sorong, Adapun dari penelitian ini hasil menunjukkan bahwa ektrak kasar bawang putih memiliki daya penghambatan terhadap bakteri E.coli yang dapat dilihat pada gambar 2 .

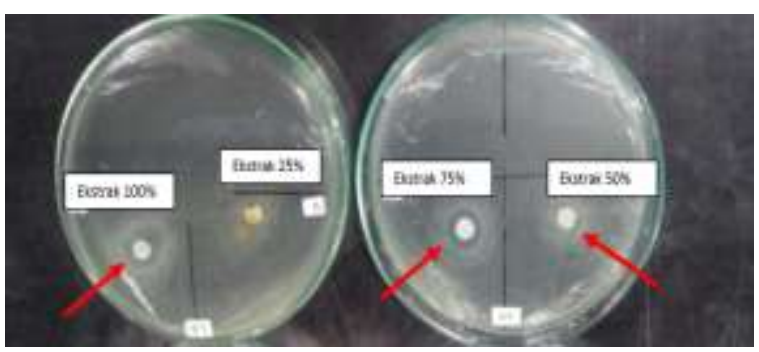

Gambar 2. Hasil pengujian antibakteri menggunakan kertas cakram paad media NA, terhadap bakteri E.coli, dengan perlakuan pemberian ekstrak kasar bawang putih tunggal dengan variasi konsentrasi $25 \%$, $50 \%, 75 \%$, dan $100 \%$

Berdasarkan pada tabel 1 tersebut dapat terlihat bahwa ektrak kasar bawang putih menghasilkanya zona hambat yang semakin besar seiring dengan meningkatnya konsentransi, sehingga dapat diasumsikan bahwa adanya hubungan berbanding lurus antara konsentarsi dengan hasil zona hambat. Hasil pengujian menunjukkan bahwa diameter zona hambat yang dihasilkan meningkat seiring dengan peningkatan konsterat ekstrak. Sedangkan pada kontrol negatif berupa aquabides (air destilasi) tanpa perlakuan penambahan zat penghambat tidak memiliki zona bening sehingga dapat dipastikan zona hambat yang dihasilkan murni berasal dari ekstrak bawang putih tunggal. Konsentrat 25\% menghasilkan nilai 
rata-rata zona hambat $7,8 \mathrm{~mm}$; konsentrat $50 \%$ zona hambat $9,4 \mathrm{~mm}$; konsentrat $75 \%$ zona hambat $10,8 \mathrm{~mm}$; dan zona hambat konsentrat $100 \%$ sebesar $12,8 \mathrm{~mm}$, bila dibandingkan dengan kontrol positif pemberian antibiotik amoxicillin, hasilnya masih berbeda jauh yaitu rata-rata $21,8 \mathrm{~mm}$.
Hal tersebut menunjukkan bahwa pemberian ekstrak bawang putih tunggal tidak memiliki efek yang sama dengan kontrol positif dalam hal ini antibiotik amoxicillin dalam menghambat bakteriuria E.coli.

Tabel 1. Hasil diameter zona hambat uji antibakteri ekstrak kasar bawang putih tunggal terhadap bakteriuria E.coli

\begin{tabular}{|l|l|c|c|c|c|c|c|}
\hline \multirow{2}{*}{ No } & Kode sampel isolat & \multicolumn{6}{|c|}{ Penghambatan Konsentrasi Ekstrak (mm) } \\
\cline { 3 - 7 } & & $0 \%(1)$ & $25 \%(2)$ & $50 \%(3)$ & $75 \%(4)$ & $100 \%(5)$ & $\begin{array}{c}\text { Kontrol (+) } \\
\text { Amoxicillin }\end{array}$ \\
\hline 1 & $235985 \mathrm{~A} 1$ & 0 & 7 & 7 & 8 & 9 & 15 \\
\hline 2 & $235985 \mathrm{~A} 2$ & 0 & 7 & 9 & 11 & 12 & 17 \\
\hline 3 & $235985 \mathrm{~A} 3$ & 0 & 7 & 7 & 8 & 9 & 15 \\
\hline 4 & $235985 \mathrm{~A} 4$ & 0 & 6 & 7 & 8 & 11 & 16 \\
\hline 5 & $019 \mathrm{~A} 1$ & 0 & 7 & 8 & 9 & 10 & 15 \\
\hline 6 & $019 \mathrm{~A} 2$ & 0 & 8 & 9 & 10 & 11 & 16 \\
\hline 7 & $237950 \mathrm{~A} 1$ & 0 & 8 & 8 & 10 & 16 & 31 \\
\hline 8 & $237950 \mathrm{~A} 2$ & 0 & 7 & 8 & 9 & 12 & 34 \\
\hline 9 & $019 \mathrm{~B} 1$ & 0 & 8 & 9 & 10 & 15 & 17 \\
\hline 10 & $019 \mathrm{~B} 2$ & 0 & 8 & 9 & 11 & 14 & 18 \\
\hline 11 & $237951 \mathrm{~B} 1$ & 0 & 7 & 9 & 10 & 11 & 22 \\
\hline 12 & $237951 \mathrm{~B} 2$ & 0 & 7 & 10 & 12 & 13 & 18 \\
\hline 13 & $985 \mathrm{~B} 1$ & 0 & 8 & 11 & 12 & 13 & 35 \\
\hline 14 & $985 \mathrm{~B} 2$ & 0 & 8 & 10 & 12 & 13 & 36 \\
\hline 15 & $418 \mathrm{~A} 1$ & 0 & 9 & 9 & 10 & 12 & 18 \\
\hline 16 & $418 \mathrm{~A} 2$ & 0 & 6 & 10 & 11 & 12 & 16 \\
\hline 17 & $418 \mathrm{~A} 3$ & 0 & 7 & 10 & 11 & 12 & 16 \\
\hline & Rata-rata (mm) & 0 & $7,8 \pm 0,78$ & $9,4 \pm 1,18$ & $10,8 \pm 1,3$ & $12,8 \pm 1,8$ & $21,8 \pm 7,73$ \\
\hline
\end{tabular}

Pengujian analisis data menggunakan uji statistik one way Anova, dengan nilai Pvalue $=0,000$, dan karena $0,000<0,05$, maka H0 ditolak, dengan arti bahwa terdapat perbedaan uji antibakteri pada beberapa konsentrasi ekstrak bawang putih dengan variasi konsentrasi; 0\%, 25\%, 50\%, 75\%, dan 100\%. Berdasarkan perbedaan tersebut maka dilakukan uji lanjutan menggunakan Uji Post Hoc dengan Uji Tuckey, yang diperoleh hasil terdapat perbedaan signifikan dari variasi konsentrasi tersebut. Oleh karena itu, dapat dikatakan bahwa ekstrak bawang yang paling efektif digunakan sebagai anti bakteri adalah konsentrasi 100\% (setelah amoxcillin).

\section{KESIMPULAN}

Pemberian ekstrak bawang putih tunggal sebagai zat antibakteri terhadap bakteriuria E. coli, memiliki aktivitas menghambat yang 
di tunjukkan dengan terbentuknya zona hambat yaitu dengan konsentrat maksimal $100 \%$ rata-rata zona hambat $12,81 \mathrm{~mm}$, yang berdasarkan analisis data Anova memiliki perbedaan nyata dibandingkan dengan konsentrat $0 \%$, 25\%, 50\%, dan 75\%. Hasil pengujian menunjukkan bahwa diameter zona hambat yang dihasilkan meningkat seiring dengan peningkatan konsterat ekstrak.

\section{UCAPAN TERIMAKASIH}

Kementerian Riset dan Teknologi / Badan Riset dan Inovasi Nasional, dan Lembaga Penelitian dan Pengabdian Masyarakat Universitas Nahdlatul Ulama Purwokerto

\section{DAFTAR PUSTAKA}

Abiy, Ephrem, and Asefaw Berhe. 2016. "AntiBacterial Effect of Garlic (Allium Sativum) against Clinical Isolates of Staphylococcus Aureus and Escherichia Coli from Patients Attending Hawassa Referral Hospital, Ethiopia." Journal of Infectious Diseases and Treatment 02(02): 1-5.

Adhuri, Iesha Kinanti, Tri Nur Kristina, and Arlita Leniseptaria Antari. 2018. "Perbedaan Potensi Antibakteri Bawang Putih Tunggal Dengan Bawang Putih Majemuk Terhadap Salmonella Typhi." Diponegoro Medical Journal (Jurnal Kedokteran Diponegoro) 7(2): 415-23.

Arimaswati, Arimaswati, Yessy Toding Mendaun, and Yenti Purnamasari. 2019. "Uji Aktivitas Antibakteri Ekstrak Kasar Bawang Putih (Allium Sativum ) Terhadap Bakteri Shigella Dysenteriae Yang Resisten Terhadap Ampisilin." Medula 6(2): 541-46.

Brubaker, Linda, and Alan J. Wolfe. 2017. "The Female Urinary
Microbiota/Microbiome: Clinical and Research Implications." Rambam Maimonides Medical Journal 8(2): e0015.

Eka, Christine, Wulandari Harianto, Tabita Hasian, and Tri Dewanti Widyaningsih. 2018. "PADA TIKUS WISTAR JANTAN YANG DIINDUKSI PARASETAMOL The Effectiveness Hepatoprotector of Single Clove Garlic Extract against Paracetamol Induced Hepatotoxicity in Male Wistar Rats." 6(4): 1-10.

Gaherwal, S, F Johar, N Wast, and M M Prakash. 2014. "Anti-Bacterial Activities of Allium Sativum Against Escherichia Coli, Salmonella Ser. Typhi and Staphylococcus Aureus." International Journal of Microbiological Research 5(1): 19-22.

Katrin, Dina, Nora Idiawati, and Berlian Sitorus. 2015. "Uji Aktivitas Antibakteri Dari Ekstrak Daun Malek ( Litsea Graciae Vidal) Terhadap Bakteri Stapylococcus Aureus Dan Escherichia Coli." Jkk 4(1): 7-12. http://jurnal.untan.ac.id.

Petropoulos, Spyridon et al. 2018. "Antimicrobial and Antioxidant Properties of Various Greek Garlic Genotypes." Food Chemistry 245(August 2017): 7-12.

Pusat Penelitian, Pengembangan dan Informasi (PUSLITFO). 2019. September Data Penempatan Dan Perlindungan PMI.

Rahman, Ave Olivia. 2017. “Uji Kepekaan Bakteri Yang Diisolasi Dari Pasien Dengan Bakteriuria Terhadap Antibiotik Amoksisilin, Levofloksasin Dan Ciprofloksasin Di Laboratorium Mikrobiologi Rsud Raden Mattaher Jambi Periode Oktober - November 2016." JAMBI MEDICAL JOURNAL "Jurnal Kedokteran dan Kesehatan" 5(2): 87-94. https://onlinejournal.unja.ac.id/kedokteran/article/vi ew/4116. 
Republik Indonesia, Presiden. 2011.

"Peraturan Presiden RI No.64 Tahun 2011 Tentang Pemeriksaan Kesehatan Dan Psikologi Calon Tenaga Kerja Indonesia."

https://jdih.kemenkeu.go.id/fullText/2 011/64TAHUN2011PERPRES.HTM.

Schmidt, K. et al. 2017. "Identification of Bacterial Pathogens and Antimicrobial Resistance Directly from Clinical Urines by Nanopore-Based Metagenomic Sequencing." Journal of Antimicrobial Chemotherapy 72(1): 104-14. 